\title{
Particle size distributions from laboratory-scale biomass fires using fast response instruments
}

\author{
S. Hosseini ${ }^{1}$, Q. Li $^{2}$, D. Cocker ${ }^{2}$, D. Weise ${ }^{3}$, A. Miller ${ }^{4}$, M. Shrivastava ${ }^{1,5}$, J. W. Miller ${ }^{2}$, S. Mahalingam ${ }^{1}$, \\ M. Princevac ${ }^{1}$, and H. Jung ${ }^{1}$ \\ ${ }^{1}$ Department of Mechanical Engineering, University of California, Riverside, CA 92521, USA \\ ${ }^{2}$ Department of Chemical Engineering, University of California, Riverside, CA 92521, USA \\ ${ }^{3}$ USDA Forest Service, Pacific Southwest Research Station, Forest Fire Laboratory, Riverside, CA, USA \\ ${ }^{4}$ National Institutes for Occupational Safety and Health (NIOSH), Spokane, WA, USA \\ ${ }^{5}$ Pacific Northwest National Laboratory, Richland, WA, USA
}

Received: 28 February 2010 - Published in Atmos. Chem. Phys. Discuss.: 6 April 2010

Revised: 19 July 2010 - Accepted: 2 August 2010 - Published: 30 August 2010

\begin{abstract}
Particle size distribution from biomass combustion is an important parameter as it affects air quality, climate modelling and health effects. To date, particle size distributions reported from prior studies vary not only due to difference in fuels but also difference in experimental conditions. This study aims to report characteristics of particle size distributions in well controlled repeatable lab scale biomass fires for southwestern United States fuels with focus on chaparral. The combustion laboratory at the United States Department of Agriculture-Forest Service's Fire Science Laboratory (USDA-FSL), Missoula, MT provided a repeatable combustion and dilution environment ideal for measurements. For a variety of fuels tested the major mode of particle size distribution was in the range of 29 to $52 \mathrm{~nm}$, which is attributable to dilution of the fresh smoke. Comparing mass size distribution from FMPS and APS measurement $51-68 \%$ of particle mass was attributable to the particles ranging from 0.5 to $10 \mu \mathrm{m}$ for $\mathrm{PM}_{10}$. Geometric mean diameter rapidly increased during flaming and gradually decreased during mixed and smoldering phase combustion. Most fuels produced a unimodal distribution during flaming phase and strong biomodal distribution during smoldering phase. The mode of combustion (flaming, mixed and smoldering) could be better distinguished using the slopes in MCE (Modified Combustion Efficiency) vs. geometric mean diameter than only using MCE values.
\end{abstract}

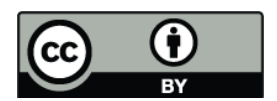

Correspondence to: H. Jung (heejung@engr.ucr.edu)

\section{Introduction}

Biomass combustion encompasses a wide range of sources including wildland fires, prescribed burning, agricultural residue/waste burning, residential wood combustion, and power generation. Since the 1970 s, considerable effort has been devoted to characterizing the products associated with biomass combustion in general. In the United States, intentional biomass burning (prescribed burning) is regulated by the Clean Air Act. Prescribed burning is the planned use of fire under specified environmental and meteorological conditions to accomplish specific vegetation management objectives. These objectives include the removal of hazardous fuel accumulations, wildlife habitat improvement, forest regeneration, and mimicking the natural role of fire. In order to utilize prescribed burning, managers must provide estimates of the quantity of certain combustion products that will be produced before air quality regulators issue burn permits. These products of combustion include particulate matter (PM) released into the atmosphere (Chi, 1979; Levine, 1996; Goldammer, 2009). Particles can affect the radiation budget of the earth depending on their size distribution, morphology and their chemical composition. There is growing evidence of the role of particle size distribution and its adverse effect on human health following transport and deposition of particles (Pope and Dockery, 2006). Currently in the United States, the production of particles smaller than $2.5 \mu \mathrm{m}$ is regulated due to the adverse impacts on human health and visibility.

Particle size distribution from biomass combustion evolves due to condensation/coagulation within the plume and photochemical aging downstream of the fire. The

Published by Copernicus Publications on behalf of the European Geosciences Union. 
particle size distribution can also differ by combustion phase (ignition/flaming/smoldering), fuel condition (live, dead and varying moisture content), fuel configuration (dense vs. light and plain vs. sloped terrain), and fuel types (foliage, log, branch). Due to the importance of particle size distribution and its impact on air quality, climate modeling and health effects, particle size distributions from diverse biomass combustion conditions have been reported (Janhall, 2009; Hays et al., 2005; Capes et al., 2008).

Particle size distributions from biomass burning have been studied for a variety of fuels (Le Canut, 1996; Posfai et al., 2003, 2004; Capes et al., 2008). A wide variety of instruments have been used to measure particle size distribution; Laser Optical Particle Counter, Aerosol Time-OfFlight Mass Spectrometer (ATOFMS), Differential Mobility Particle Sizer (DMPS)(Hedberg et al., 2002; Sullivan et al., 2008), Scanning Mobility Particle Sizer (SMPS) (Hays et al., 2002; Hays et al., 2005), Transmission Electron Microscopy (TEM) analysis (Posfai et al., 2003; Posfai et al., 2004; Chakrabarty et al., 2006), Micro Orifice Uniform Deposit Impactor (MOUDI) (Hays et al., 2005; Engling et al., 2009), and Passive Cavity Aerosol Spectrometer Probe (PCASP) (Capes et al., 2008).

Previous studies have shown a wide variation in particle size distribution due to differing combustion and measurement conditions. Hays et al. (2002) reported unimodal distribution using a SMPS. They used open combustion of a fuel to simulate combustion of fuel in the field. They reported geometric mean diameters between $0.1-0.2 \mu \mathrm{m}$. Due to the use of a small enclosure $\left(28 \mathrm{~m}^{3}\right)$, their particles may have grown by condensation and coagulation within the enclosure. Le Canut et al. (1996) measured particle size distribution using a laser optical particle counter in their airborne study during a savanna fire. They reported two mass modes: one in $0.2-$ $0.3 \mu \mathrm{m}$ and the other above $2 \mu \mathrm{m}$. Chakrabarty et al. (2006) measured particle size distribution from laboratory combustion of eight different fuels using SMPS and image analysis. Projected area equivalent diameter peaks ranged from 30 to $200 \mathrm{~nm}$ for wet (moisture content $(\mathrm{MC})=20 \%$ on dry mass basis) and dry (MC $=5-10 \%)$ fuels. Major mode diameter ranged between $40-45 \mathrm{~nm}$ for three out of six burns (see their Fig. 12) for dry fuels they tested. To authors' knowledge none of these previous studies captured the temporal evolution of size distribution due to the relatively slow response rate of the instruments. For example, the SMPS requires 2 min to measure one size distribution. Janhäll et al. (2009) parameterized particle number emissions by applying complicated fittings to published experimental data. They pointed out that well defined laboratory experiments should help validate their finding and enable a better understanding of particle emission/formation mechanisms.

A study to characterize smoke emissions from prescribed burns in chaparral and Madrean oak woodlands in the southwestern United States was initiated in 2008. Detailed characterization of gaseous and particulate emissions is being made in laboratory and field settings. Changes in and transport of emissions from the source downwind are being measured and modeled for inclusion in air quality models such as CMAQ (Byun, 2006). The objective of this paper is to characterize particle size distribution from the laboratory component of the study. A suite of fast-response online instruments were applied to measure evolution of particle size distribution from fire ignition to extinction to capture transient and integrated characteristics of particle size distribution from biomass burning. To the best of our knowledge, the current study reports fast time-dependent (1s interval) size distribution of particle-phase emissions and their characteristics from biomass burning in detail for the first time.

\section{Experimental}

\subsection{Combustion lab facility}

Experiments were conducted in the combustion laboratory at the USDA Forest Service's Fire Science Laboratory (FSL), Missoula, MT. A detailed description of the characteristics of the facility can be found in Christian et al. (2004). The facility measures $12.5 \mathrm{~m}$ by $12.5 \mathrm{~m}$ and is $22 \mathrm{~m}$ in height. The combustion laboratory is exhausted via a $3.6 \mathrm{~m}$ diameter hood attached to a $1.6 \mathrm{~m}$ stack located in the center. Figure 1 shows a schematic of the lab. The base of the hood is above the fuel bed. The stack extends from $2 \mathrm{~m}$ above the floor to all the way up through the ceiling. The lab is slightly pressurized with pre-conditioned outside air to precisely control the temperature, and relative humidity. This ensures entrainment of all the produced emissions, making the conditions ideal for determining emissions factors. The air velocity in the chimney was set at either $1.5 \mathrm{~m} / \mathrm{s}$ or $3 \mathrm{~m} / \mathrm{s}$ by controlling the exhaust fan speed to maintain proper entrainment of fresh air.

\subsection{Particle measurement system}

The sampling platform (Fig. 1) is located $17 \mathrm{~m}$ above the floor surrounding the stack; this is where all particle measurement instruments were placed. Figure 2 shows schematic of the sampling system. First sampling flow was taken from the isokinetic sampling port installed at the height of the sampling platform in the stack. The sample flow was diluted using a mini dilution tunnel at 1:13.5 ratio. The diluted aerosol flow wass directed to a $\mathrm{PM}_{10}$ impactor, then distributed to a Fast Mobility Particle Sizer (FMPS-model 3091, TSI ${ }^{1}$ ), an Aerodynamic Particle Sizer (APS-model 3321, TSI) and a Condensation Particle Counter (CPC Model 3775, TSI). Other online and offline instruments were used for physical

\footnotetext{
${ }^{1}$ The use of trade names is provided for informational purposes only and does not constitute endorsement by the US Department of Agriculture.
} 


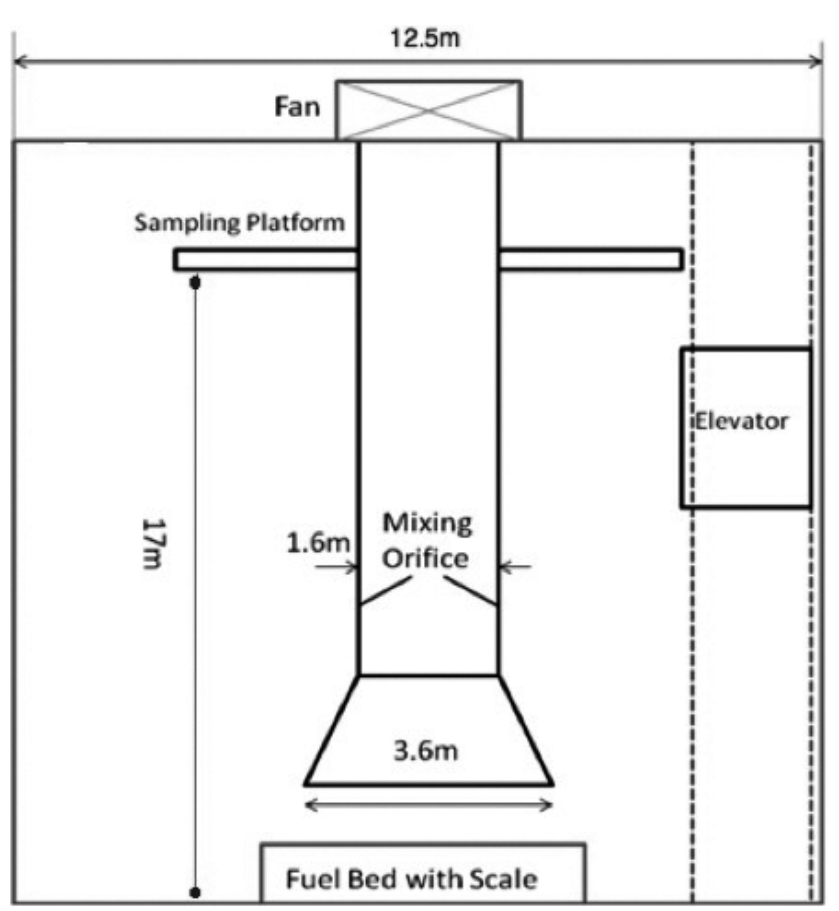

Fig. 1. Schematic drawing of combustion laboratory, USDA Forest Service Fire Sciences Laboratory, Missoula, MT. Detailed characteristics of the facility are described in Christian et al. (2004).

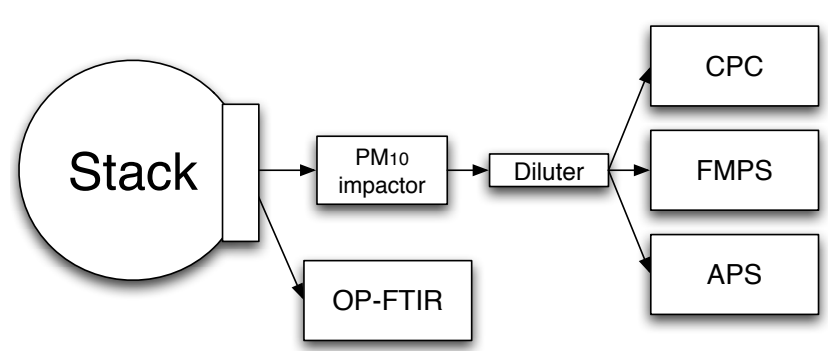

Fig. 2. Schematic of measurement system.

and chemical characterization of the particles but are not reported in this paper.

The Fast Mobility Particle Sizer Spectrometer (FMPS, TSI Model 3091) is capable of measuring mobility diameter of the particles. The instrument is made of two concentric cylinders (classification columns), a corona diffusion charger, and 32 electrometers, which covers the particle size range of 5 to $560 \mathrm{~nm}$. The stream containing positively charged particles flows along with sheath air. The high voltage between the two cylinders carries the particles from the side where they are introduced to the other side that has the electrometers. Close to the top of the column, the particles with higher electrical mobility are collected, and further downstream the particles with lower electrical mobility are collected (TSI man- $\mathrm{ual}^{2}$ ). Electrical mobility, $Z$ is defined as below

$$
Z=\frac{n e C}{3 \pi \mu_{g} D_{m}}
$$

Where $n, e, C, \mu_{g}, D_{m}$ are number of charge, unit charge of an electron, slip correction factor, gas viscosity and particle mobility diameter.

The aerodynamic diameter $D_{a}$ is the diameter of the unit density $\left(\rho_{p}=1 \mathrm{~g} / \mathrm{cm}^{3}\right)$ sphere that has the same settling velocity as the particle (Hinds, 1982). The Aerodynamic Particle Sizer (APS, TSI Model 3321) is capable of measuring particle size distributions in the size range between 0.5 and $20 \mu \mathrm{m}$. The sample particles are accelerated as the carrier gas flows through a converging nozzle. Due to the inertia, particles cannot accelerate as fast as the gas and the velocity lags that of the gas. Particle size is related to this velocity lag and that is measured at the nozzle exit when particles pass through two closely spaced laser beams. The time of flight between the two laser beams is then used to calculate the aerodynamic diameter (Rader et al, 1990; Wang and John, 1987). Chen et al. (1985) found a unique calibration curve existed between a particle Stokes number and its velocity normalized by the gas velocity.

The Stokes number is defined as

$S t=\frac{\rho_{p} D_{p}^{2} V_{g} C}{9 \mu_{g} W}$

where $\rho_{p}, D_{p}, V_{g}, C, \mu_{g}, W$ are particle density, particle diameter, gas velocity, slip correction factor, gas viscosity and diameter of the nozzle at the exit. The APS measured aerodynamic diameter requires correction for non-Stokesian effects when particle Reynolds diameter becomes greater than 0.5 (Wang and John, 1987). A conversion of aerodynamic diameter into mobility diameter requires a correction factor involving dynamic shape factor and density of particles (Stöber, 1971). The particle Reynolds numbers are reported as $0.65,4.8,24$ and 103 for diameters of 1.0, 2.1, 5, and $15 \mu \mathrm{m}$ by Wang and John (1987) for the APS at the nozzle flow velocity of $150 \mathrm{~m} / \mathrm{s}$. The current study does not aim to measure shape factor and density of particles for a conversion from aerodynamic to mobility diameter.

\subsection{Gas measurement system}

Every molecule has its own specific IR radiation absorption pattern. Researchers have used this fact in Fast Fourier InfraRed (FTIR) spectroscopy. If a beam of IR is passed through smoke, and the IR spectrum is recorded, the acquired graph will have peaks that are due to molecules present in the smoke (Yokelson et al., 1997; Goode et al., 1999). The OPFTIR instrument used in this study included a Bruker MatrixM IR Cube spectrometer and a thermally stable open white

\footnotetext{
${ }^{2}$ http://www.tsi.com/uploadedFiles/Product_Information/ Literature/Spec_Sheets/3091FMPS.pdf
} 
cell. The white cell was positioned on the sampling platform approximately $17 \mathrm{~m}$ above the fuel bed so that the open white cell spanned the stack directly in the rising emissions stream. The white cell path length was set to $58 \mathrm{~m}$. Several extensive tests were performed to optimize the many sampling parameters, including duty cycle, sample frequency, and spectrometer options to choose a spectral resolution of $0.67 \mathrm{~cm}^{-1}$ and spectra were acquired every $1.5 \mathrm{~s}$ (four co-added spectra in $1.5 \mathrm{~s}$ ) beginning several minutes prior to the fire and continuously until the end of the fire. A pressure transducer and two temperature sensors were located adjacent to the optical path and were logged on the instrument computer and used for spectral analysis.

The Open-Path Fourier Transform infrared (OP-FTIR) spectrometer was used to monitor concentrations of $\mathrm{CO}$ and $\mathrm{CO}_{2}$ for this study. These concentrations were used to calculate a Modified Combustion Efficiency (MCE). MCE is defined as the amount of carbon released as $\mathrm{CO}_{2}$ divided by the amount of carbon released as $\mathrm{CO}_{2}$ plus $\mathrm{CO}$ (Ward et al., 1996; Ward, 1993).

Since $\mathrm{CO}_{2}$ and $\mathrm{CO}$ account for about $95 \%$ of carbon released during biomass combustion, the MCE is a good surrogate for true combustion efficiency. Ward et al. (1993) classifiedcombustion conditions into three phases by MCE: flaming when MCE $>0.97$, mixed when $0.97 \geq \mathrm{MCE}>0.85$ and smoldering when $0.85 \geq \mathrm{MCE}>0.75$.

\subsection{Experimental fires}

Fuel characterization and fuel bed configuration are very important parameters to determine particle emissions and formations. Yet many previous studies are lacking this critical information in their publications (Reid et al., 2005). In the present work, a total of 44 burns, composed of 8 different types of wildland fuels (Table 1), were conducted. The fuels were collected from California (Ft. Hunter-Liggett, Vandenberg Air Force Base) and Arizona (Ft. Huachuca). The fuel types selected for study are composed primarily of living vegetation. The chaparral fuel type is actually mixtures of shrub species that grow together in the mediterranean climate of California and Baja California. Many of the shrub species in this climate have developed similar physical characteristics to minimize water loss such as leaves with waxy cuticles which pyrolyze at low temperatures (Susott, 1982). The shrub canopies are relatively porous which facilitates fire spread. Fires burning in these fuel beds are typically intense with relatively high rates of energy release. In the Madrean oak fuel types, the woodland type consists of oak trees with an understory of shrub species related to chaparral species and the savanna type consists of oak trees with an understory of native and introduced grasses. Fuels were harvested from the three locations and shipped to Missoula where they were stored for several weeks prior to the experiments. During this time, the fuels lost most of the moisture which was present at the time of harvest.

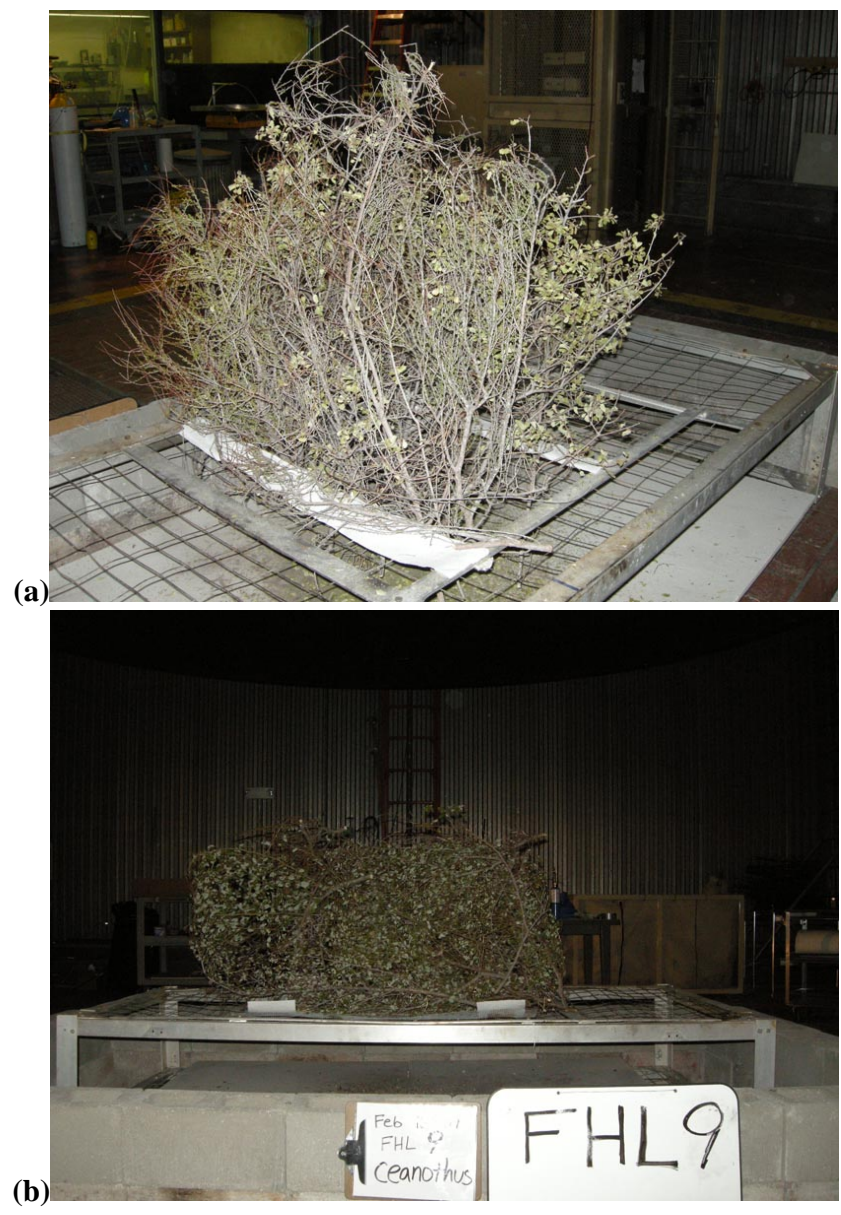

Fig. 3. Two pictures showing fuel and fuel bed, before the fuel is lit on fire.

A small amount of isopropyl alcohol (generally less than $50 \mathrm{cc}$ ) was used initially to get a quick even ignition of the fuel bed. Eighteen of 44 of the southwestern fuel beds (chamise, ceanothus, manzanita, and California sagebrush - see Table 1) were ignited in this manner using a propane torch. No alcohol was used to enhance ignition in the remaining fuel beds. With the exception of the masticated mesquite fuel type which was created by mowing down and grinding the shrubs, the natural fuel beds tend to have a vertical orientation in the natural setting (Fig. 3a). We attempted to burn the fuels in a vertical orientation with limited success so the fuels were oriented horizontally (Fig. 3b). Average consumption (mass basis) of the chamise/scrub oak fuels oriented vertically was $30 \%$. Consumption of horizontally oriented fuel beds increased to $90 \%$. Bulk characteristics of the fuel beds are found in Table 2. Average moisture content (oven-dry mass basis, ASTM D4442-07) of the fuel beds at the time of burning ranged from 4 to $33 \%$ which is similar to fuel moistures in dead fuels. Moisture content in these live fuels seldom decreases below $50 \%$ in the field. The initial ovendry mass in the fuel beds ranged from 670 to $4630 \mathrm{~g}$. Bulk 
Table 1. Fuel type species composition and abbreviations.

\begin{tabular}{lll}
\hline Fuel type & Fuel Code & Plant Species \\
\hline Chamise/scrub oak & CHS & Adenostomafasciculatum, Quercusberberidifolia \\
Ceanothus & CEA & Ceanothusleucodermis \\
Coastal sage scrub & COS & Salvia mellifera, Ericameriaericoides, Artemisia californica \\
California sagebrush & CAS & Artemisia californica, Ericameriaericoides \\
Manzanita & MAN & Arctostaphylosrudis, Arctostaphylospurissima \\
Oak savanna & OAS & Quercusemoryi, Eragrostislehmanniana \\
Oak woodland & OAW & Quercusemoryi, Arctostaphylospungens \\
Masticated mesquite & MES & Prosopisvelutina, Baccharissarothroides \\
\hline
\end{tabular}

Table 2. Fuel and bed properties.

\begin{tabular}{|c|c|c|c|c|c|c|}
\hline Fuel type & $n$ & Moisture content (\%) & Fuel bed dry mass (g) & Bulk density $\left(\mathrm{km} /{ }^{3}\right)$ & Packing ratio ${ }^{\mathrm{a}}$ & Consumption $(\%)$ \\
\hline Chamise/Scrub Oak (CHS) & 6 & 11.9 & 2079 & 8.6 & 0.015 & 38 \\
\hline Ceanothus (CEA) & 6 & 10.2 & 2007 & 5.8 & 0.010 & 54 \\
\hline Coastal Sage Scrub (COS) & 5 & 9.3 & 2299 & 6.0 & 0.010 & 95 \\
\hline California Sagebrush (CAS) & 6 & 9.0 & 2460 & 6.4 & 0.011 & 93 \\
\hline Manzanita (MAN) & 6 & 12.6 & 2906 & 7.6 & 0.013 & 94 \\
\hline Oak Savanna (OAS) & 5 & 14.3 & 2788 & 7.3 & 0.012 & 91 \\
\hline Oak Woodland (OAW) & 5 & 32.8 & 2054 & 5.3 & 0.009 & 95 \\
\hline Masticated Mesquite (MES) & 5 & 4.3 & 1831 & 14.3 & 0.024 & 92 \\
\hline
\end{tabular}

a Packing ratio = bulk density/particle density. Assumed particle density of $593 \mathrm{~kg} \mathrm{~m}^{-3}$ (average from Countryman, 1982).

density of the fuel beds ranged from 5.8 to $14 \mathrm{~kg} / \mathrm{m}^{3}$ and the packing ratio (defined as the ratio of fuel bed bulk density to fuel particle density) ranged from 0.010 to 0.024 . These packing ratios are similar to those reported for laboratory fire spread experiments (Weise et al., 2005), but they are 1 to 2 orders of magnitude larger than packing ratios observed in the field which indicates the fuel beds were less porous than natural fuel beds. While our initial intent was to burn fuel beds similar to those found naturally, the fuel beds in the lab experiment were much drier with higher bulk densities than the fuel types they represent.

\section{Results and discussion}

\subsection{Particle size distribution from 7 to $520 \mathrm{~nm}$ measured by FMPS}

Figure 4a shows averaged particle size distribution for different fuels as measured by FMPS. The size distribution is averaged over the time from ignition to the end of sampling (absolute $\mathrm{CO}$ concentration $1 \mathrm{ppm}$ ) and over at least three burn replicates for each fuel type. Averaged size distributions were unimodal for many fuel types. Interestingly, a few fuel types showed biomodal distributions, with the minor (meaning lower concentration) mode around $10 \mathrm{~nm}$. The major mode varies from 29 to $52 \mathrm{~nm}$ for fuels tested. This is a very narrow range considering the diverse fuels tested. Consistent technique was used to minimize experimental errors in order to detect differences between species. The similarity of the size distribution among fuels tested can be attributable to the systematic burning and sampling method.The combustion facility in Missoula was designed to divert all the generated smoke into the chimney. This allows enough dilution of the particles so that particle sizes measured and reported in this facility are smaller than those from other studies. Chakrabarty et al. (2006) used the same combustion facility in Missoula for their experiment. They reported particle Count Median Diameter (CMD) varying from 30 to $70 \mathrm{~nm}$ for dry fuels (sage brush, poplar wood, ponderosa pine wood, ponderosa pine needles, white pine needles, Montana grass, dambo grass, tundra core) but they found the CMD increases to $120-140 \mathrm{~nm}$ for wet fuels (tundra core and Montana grass) from their SEM measurement. Hays et al. (2005) measured size distribution from open burning of agricultural biomass (wheat straw). The open burning was conducted in an enclosure and the particles were diluted from 1:25 to 36 and measured by a SMPS. They reported a biomodal distribution and suggested that one mode is characterized by nucleation while the other represents an accumulation mode. The modes in their size distributions were around $100 \mathrm{~nm}$. Their measured SMPS scans take 60 to $120 \mathrm{~s}$. Considering characteristics of biomass burning this is not fast enough to capture the transient phenomena. The background particle size distribution 

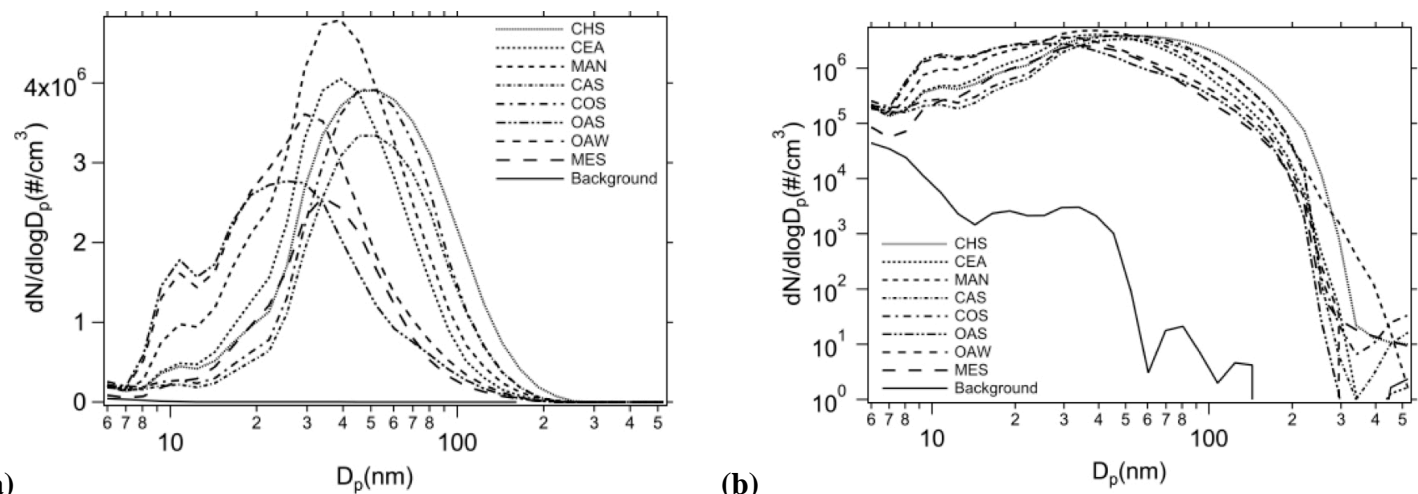

(a)

(b)
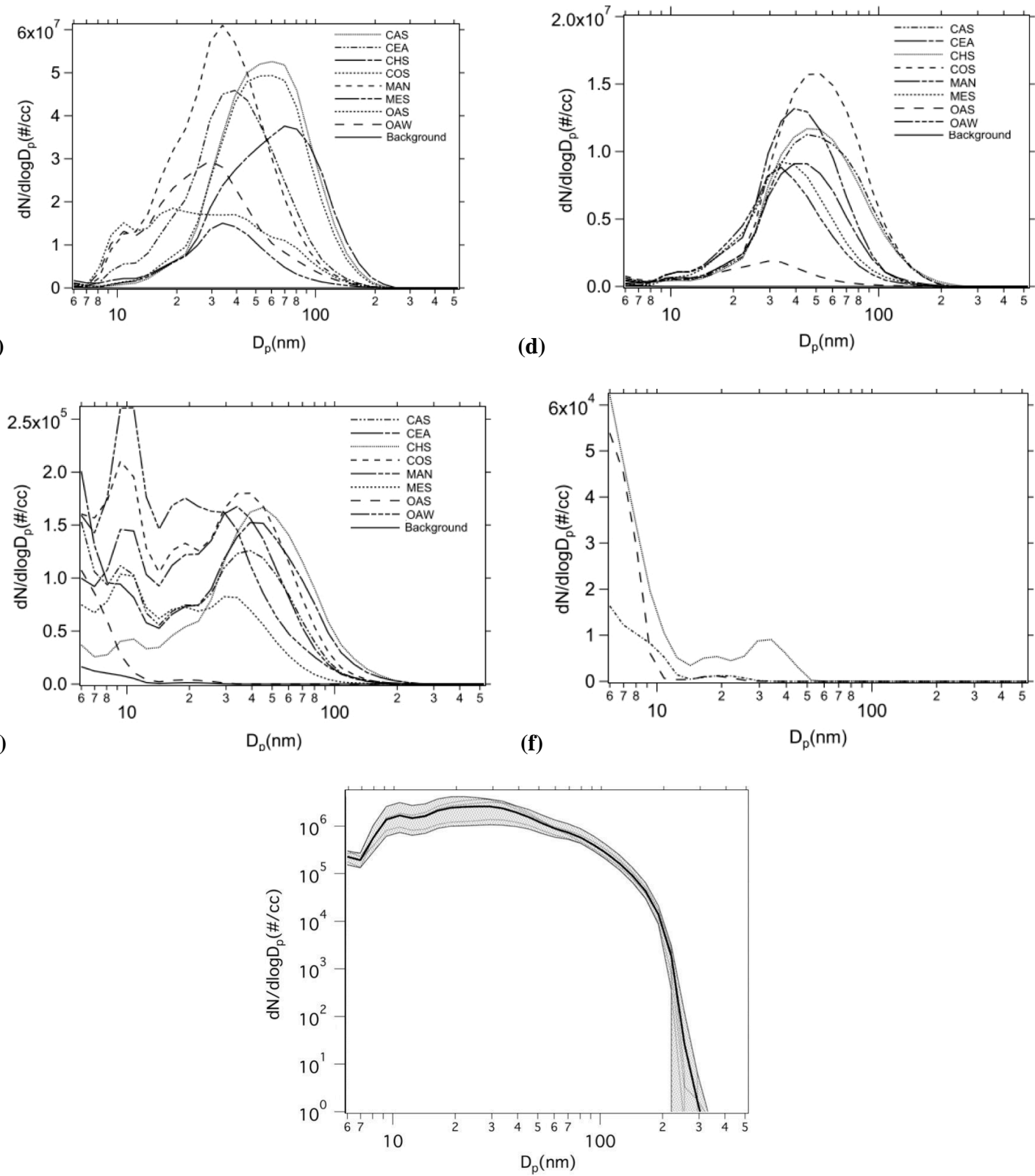

Fig. 4. Particle size distributions corresponding to (a) whole burn (linear) (b) whole burn (log-log) (c) Flaming, (d) Mixed, and (e) Smoldering phases (f) presents background levels measured by FMPS (g) variation of measurements. 
was obtained by averaging size distributions measured before ignition for seven burns which were conducted consecutively in one experimental day and plotted with averaged size distributions in log scale as shown in Fig. 4b. Figure $4 \mathrm{~b}$ also shows that particle concentration decreased sharply above $200 \mathrm{~nm}$.

While some other studies report combustion conditions of biomass burn only by using integrated or averaged MCE over the whole burn, we attempted to segregate the mode of combustion during each burn using instantaneous MCE value and other indicators (i.e. slopes in MCE vs geometric mean diameter curve). The average size distributions of Fig. 4a and $b$ were segregated into three burning conditions: flaming, mixed and smoldering by MCE. This division was done by plotting geometric mean diameter change as a function of MCE instead of using only Ward and Radke's criteria by MCE value. Details of this will be discussed in later section. The majority of particles were emitted during flaming therefore the shapes of size distributions during flaming were similar to that of the average of the whole burn (Fig. 4c). (Note our presentation of data in Fig. 4 is time based while some studies report particle emission per fuel mass.) Mixed phase, whichconsists of flaming and smoldering, shows unimodal distribution with the mode ranges from 30 to $50 \mathrm{~nm}$ (Fig. 4d). The particle concentration was lower than that of flaming by a factor of 5 roughly. The change between flaming and mixed mode could be observed clearly from our video recording of all burns. The size of flames was decreased noticeably at the beginning of the mixed phase compared to the flaming phase. The flame was still clearly visible during the mixed phase.

Size distribution during smoldering showed a bimodal distribution for all fuel types at around $10 \mathrm{~nm}$ (Fig. 4e). A possible explanation for this is nucleation of volatile particles as the burnt gas temperature cooled down. The particle concentration during smoldering was two orders of magnitude lower than during the flaming phase. Note that this is timebased not fuel mass-based. Analysis of fuel mass-based results will be reported in another paper. Figure $4 \mathrm{f}$ shows background particle size distribution change during a day. The background concentrations (Fig. 4f) are much lower than our measured particle concentration during the burn (Fig. 4c, d, e), which ensures that background particles did not interfere with our measurements. Figure $4 \mathrm{~g}$ shows variation of FMPS number distribution measurement for the fuel of oak savanna. Thick solid line represents average of six burns and shaded area shows variation. Table 3 shows the geometric diameter and standard deviation of size distributions for fuels tested. Similarity between geometric mean diameter for the nine fuel types is illustrated in Table 4. Notice that the standard deviations of the distributions are similar. Several of the chaparral fuel types had similiar geometric mean diameters and the two Madrean oak fuel types were also similar.
Table 3. Geometric mean diameter and the geometric standard deviations.

\begin{tabular}{lcc}
\hline Fuel type & \multicolumn{2}{c}{ In total } \\
\hline & $D_{g}(\mathrm{~nm})$ & $\sigma$ \\
California Sagebrush (CAS) & 50.72 & 1.66 \\
Ceanothus (CEA) & 39.67 & 1.64 \\
Chamise/Scrub Oak (CHS) & 52.30 & 1.62 \\
Coastal Sage Scrub (COS) & 45.30 & 1.62 \\
Manzanita (MAN) & 39.20 & 1.62 \\
Masticated Mesquite (MES) & 34.00 & 1.58 \\
Oak Savanna (OAS) & 25.00 & 1.76 \\
Oak Woodland (OAW) & 29.00 & 1.67 \\
\hline
\end{tabular}

Table 4. Species effects on particle size distribution.

\begin{tabular}{ccccccccc}
\hline Fuel Type & CAS & CEA & CHS & COS & MAN & MES & OAS & OAW \\
\hline CAS & & $\mathrm{N}^{1}$ & $\mathrm{Y}$ & $\mathrm{Y}$ & $\mathrm{N}$ & $\mathrm{N}$ & $\mathrm{N}$ & $\mathrm{N}$ \\
CEA & & & $\mathrm{N}$ & $\mathrm{Y}$ & $\mathrm{Y}$ & $\mathrm{Y}$ & $\mathrm{N}$ & $\mathrm{N}$ \\
CHS & & & & $\mathrm{N}$ & $\mathrm{N}$ & $\mathrm{N}$ & $\mathrm{N}$ & $\mathrm{N}$ \\
COS & & & & & $\mathrm{Y}$ & $\mathrm{N}$ & $\mathrm{N}$ & $\mathrm{N}$ \\
MAN & & & & & $\mathrm{Y}$ & $\mathrm{N}$ & $\mathrm{N}$ \\
MES & & & & & & $\mathrm{N}$ & $\mathrm{Y}$ \\
OAS & & & & & & & & $\mathrm{Y}$ \\
\hline
\end{tabular}

${ }^{1} \mathrm{Y}$ indicates mean geometric diameter of fuel type $1 \pm 2 \sigma$ overlaps with mean geometric diameter of fuel type $2 \pm 2 \sigma$.

\subsection{Particle size distribution from 0.5 to $20 \mu \mathrm{m}$ measured by APS}

Figure 5a shows time and cycle averaged particle size distributions from APS measurements. This was done to determine whether concentration of large particles were higher than background levels of aerosol by number and by volume. It has been reported that mass mean diameter is as large as $0.5 \mu \mathrm{m}$ (or $500 \mathrm{~nm}$ ) for aged particles from biomass burning (Reid et al., 2005). Most of these previous measurements were performed optically by aircraft measurement. Particles larger than $100 \mathrm{~nm}$ in mobility diameter were reported by previous studies which measured size distribution in the field. However, smaller particle mode was reported for particles measured in the lab (Hays et al., 2005; Keshtkar and Ashbaugh, 2007). This can be attributed to immediate dilution which prevents further coagulation and condensation. Regardless, particles larger than $0.5 \mu \mathrm{m}$ were measured using APS to determine whether there was any noticeable number or mass of particles in this size range from freshly diluted biomass smoke. The particle number distribution (Fig. 5a) showed that the concentrations are orders of magnitude lower compared to the concentrations of small particles measured by FMPS. Log conversion of Fig. 5a illustrated that the smoke particle distributions were greater than background. Background distributions (Fig. 5f) measured between each 

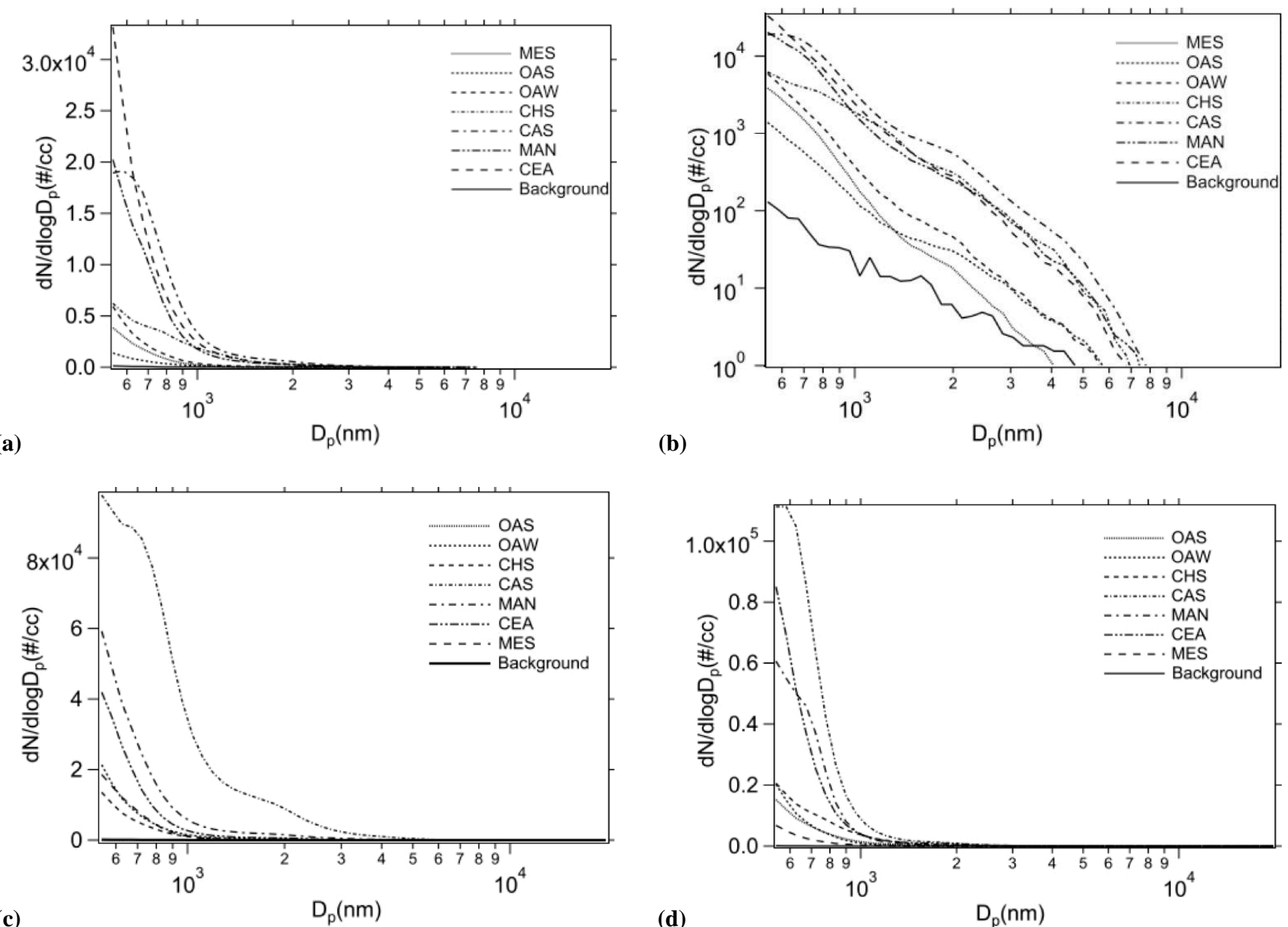

(b)
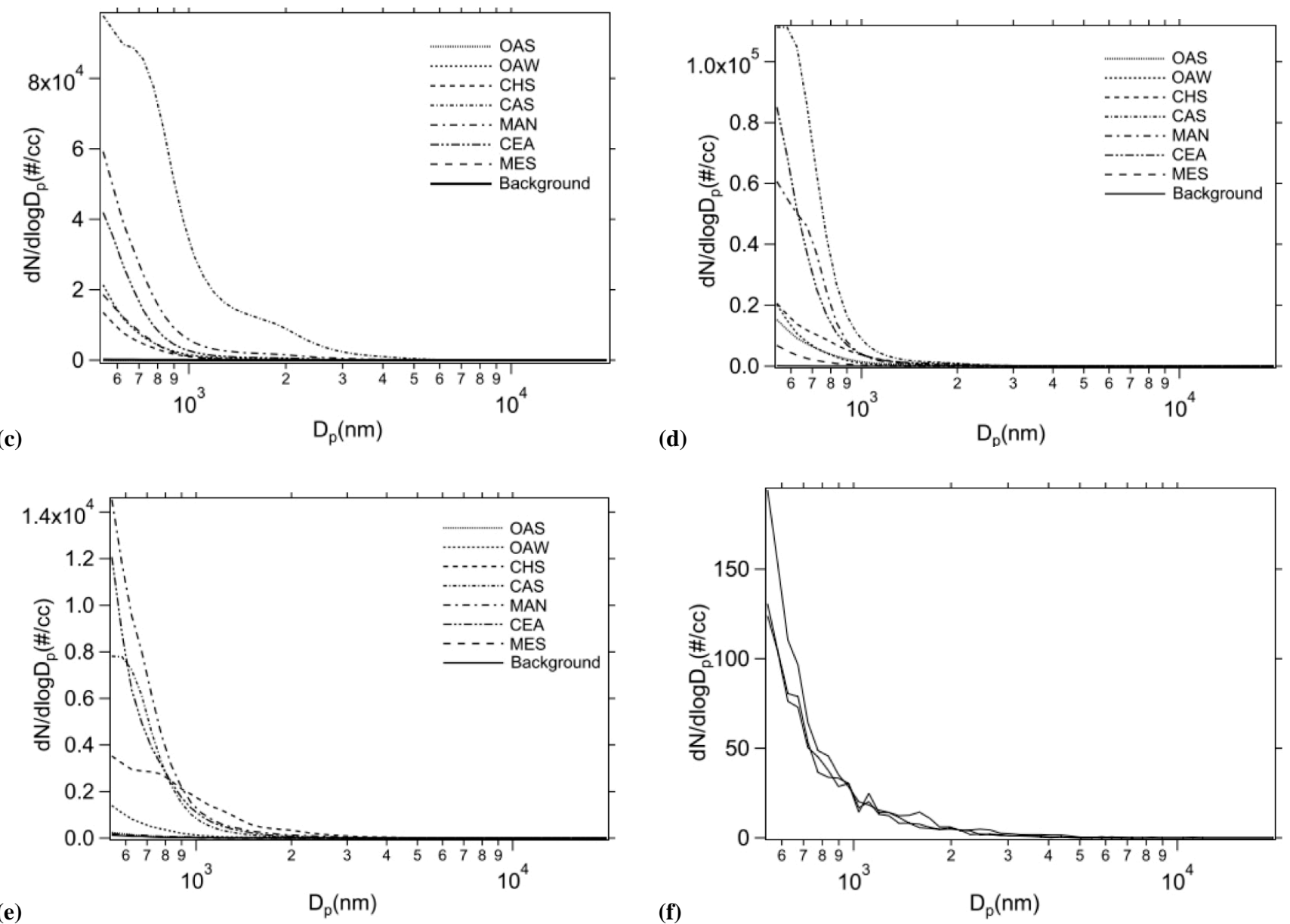

Fig. 5. Aerodynamic particle size distribution measured by APS for different phases (a) whole burn(linear) (b) whole burn(log-log) (c) Flaming (d) Mixed (e) Smoldering, and (f) corresponds to background concentration

burn during a day show that they do not vary much compared to that of small size particles (Fig. 4f). This validated that our APS measurements were not interfered by background particle size distribution. The average size distributions of Fig. 5 were separated by combustion phases using the same method used with the FMPS size distribution. Particles larger than $0.5 \mu \mathrm{m}$ were emitted mostly during flaming and mixed phases of combustion. Emissions during the smoldering phase were 


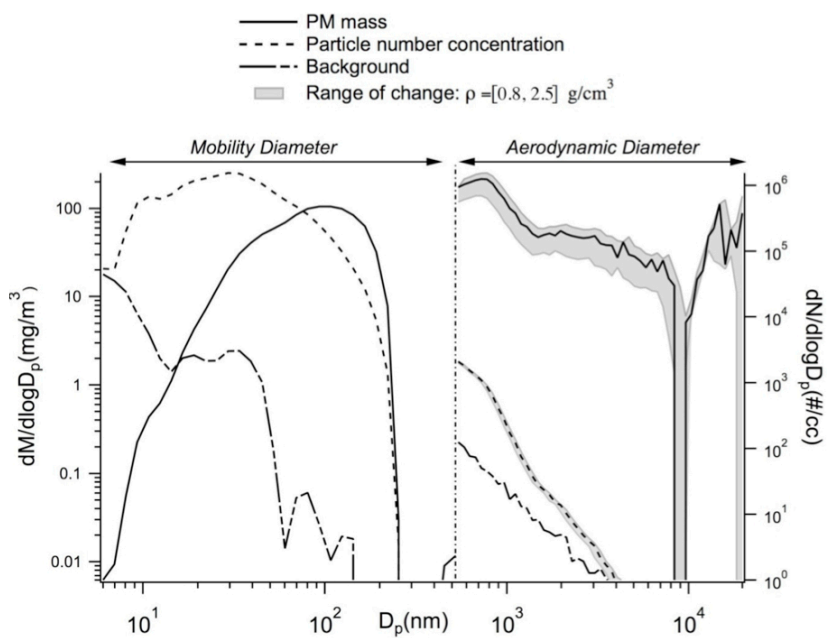

Fig. 6. Particle number and mass size distributions corresponding to a typical burn, also the background concentration.

lower by at least a factor of 4 incomparison to peak concentrations.

The mass distributions were compared between large and small particles measured by APS and FMPS. The number of fractal-like particles for the size greater than $0.5 \mu \mathrm{m}$ was insignificant based on our TEM measurement (images not shown in this paper). A range of particle densities was chosen to assess uncertainties in mass distribution taking into account the non-Stokesian effects. Figure 6 shows that the mass larger than $0.5 \mu \mathrm{m}$ attribute to $51-68 \%$ of total volume measured by APS and FMPS when particle density range of $0.8 \sim 2.5$ was assumed for non-Stokesian correction with the APS measurement. Note that the dilution was applied for all online aerosol measurements. RH of dilution air was maintained at $16.5 \pm 4 \%$. Note the size distribution by APS is in aerodynamic diameter while that by FMPS is in mobility diameter.

\subsection{Evolution of particle size distribution (FMPS+APS)}

It is extremely difficult to identify what determines evolution of particle distribution from biomass burning due to the large variability in fuel composition, fuel humidity, fuel bed arrangement and the nature of turbulent combustion. Therefore most previous studies reported either time-integrated results or snap shots of transient phenomenon. In order to understand the evolution of particle size distribution, it is instructive to examine Fig. 7 which shows the evolution of particle size distribution for a burn from initial ignition until extinction. This temporal resolution is possible due to the fast scanning ability of the FMPS and the APS (1 scan per second). The data showed that particle concentration reached a maximum during the flaming phase (confirmed by $\mathrm{CO}$ and $\mathrm{CO}_{2}$ data) and diminished to lower concentration either in unimodal or bimodal distributions. Right after ignition $\mathrm{CO}_{2}$ (a)

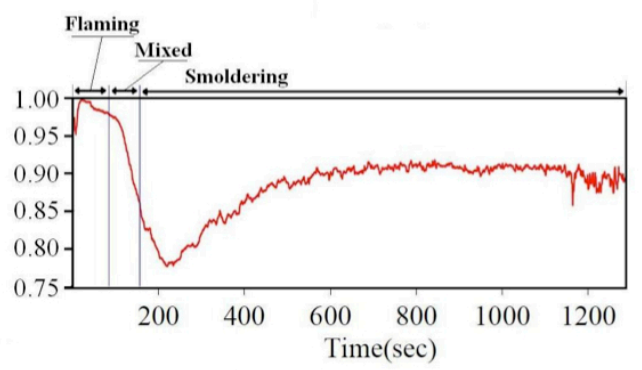

(b)

(c)
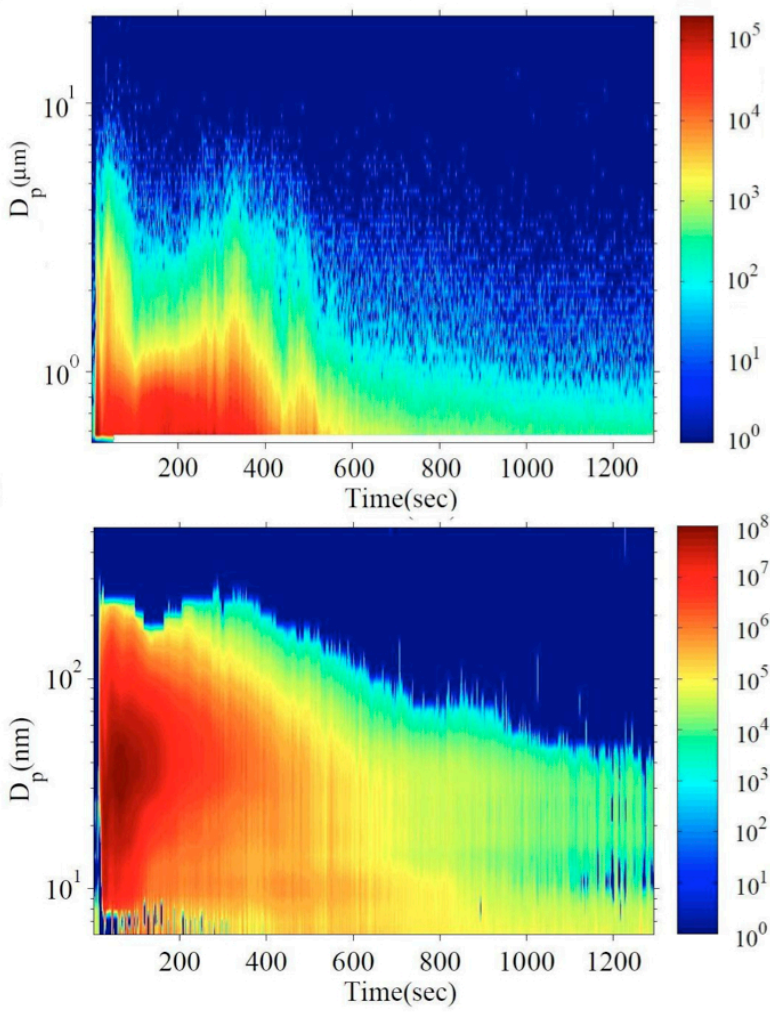

Fig. 7. (a) Modified Combustion Efficiency (MCE); Corresponding APS (b) and FMPS (c) contour graphs showing particle number size distributions.

concentration increases and that leads to increase in MCE. After the MCE reaches nearly one it starts to decrease because $\Delta \mathrm{CO}_{2} / \Delta \mathrm{CO}$ decreases as shown in Fig. 7a. During smoldering phase, $\Delta \mathrm{CO}_{2} / \Delta \mathrm{CO}$ increases again mainly due to decrease in $\triangle \mathrm{CO}$, which leads to increase of MCE value. The MCE value reaches a plateau toward the end of the smoldering phase. During the flaming phase significant particle emissions occur for the size range measured by both instruments (FMPS and APS). It is important to note that emissions of ultrafine particles $\left(D_{p}<100 \mathrm{~nm}\right)$ reduce significantly as the combustion phase progresses from flaming, mixed to smoldering phase. On the other hand high concentration of particles between 0.5 and $1 \mu \mathrm{m}$ range persist during flaming, mixed phase and even past smoldering until $400 \mathrm{~s}$ in Fig. 7b. It is noteworthy that near the end 


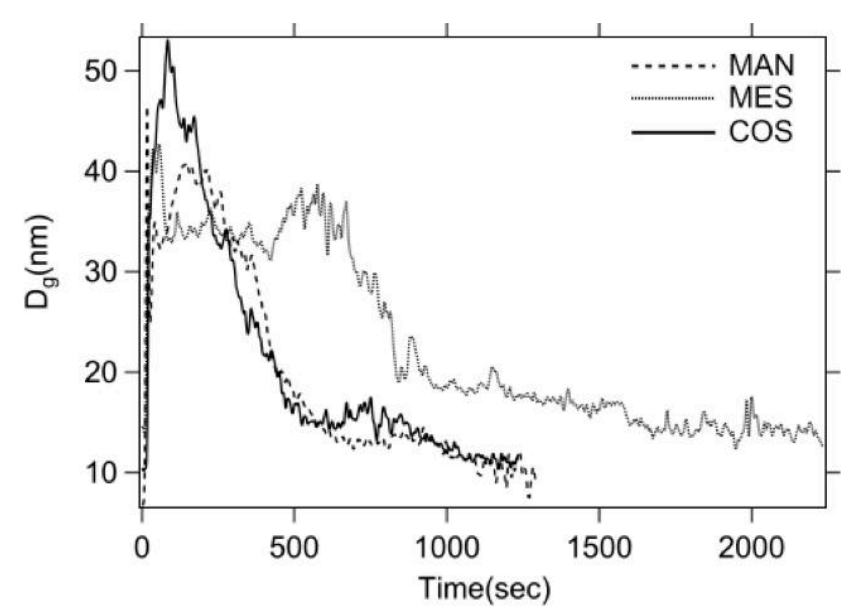

Fig. 8. Geometric Mean Diameter as a function of time for a few burns: (a) Manzanita (MAN) (b) Mesquite (MES) (c) Coastal Sage (COS).

of the smoldering phase ultrafine particles show a bimodal distribution clearly (see Fig. 7c). Values of peak concentration measured by FMPS were at least three to four orders of magnitude higher than APS concentrations during the flaming and mixed phases. Likewise, the evolution of geometric mean diameter was plotted for a few burns as illustrated in Fig. 8. These results revealed that the geometric mean diameter increases rapidly during flaming phase and decreased during mixed and smoldering phases. In Fig. 9, MCE was plotted as a function of geometric diameter for three different fuels. Ward and Radke's (1993) MCE criteria gives a guideline to distinguish different phase of combustion but it fails to give accurate distinction at specific MCE values. For example smoldering mode starts at different MCE values of $0.82,0.76$ and 0.83 for the different burns in Fig. $9 \mathrm{a}, \mathrm{b}, \mathrm{c}$. As the combustion of biomass is always dynamic instead of being steady state, either combustion or emissions parameters should evolve at a different rate and/or direction at different phase of combustion. When we plotted the MCE value against geometric mean diameter, we found that the distinction between different phases of combustion could be more clearly seen. This was also confirmed by comparing video records of the burn with Fig. 9. The geometric mean diameter increased rapidly during the flaming condition when MCE was $>0.97$. However the MCE value for the mixed phase could become smaller than what Ward and Radke (1993) define. The geometric mean diameter decreased during both mixed and smoldering conditions. While the MCE decreased as the mixed phase proceeded, the MCE value increased as the smoldering phase proceeded. As a result one can distinguish mixed phase combustion from smoldering phase combustion based on the slope change in MCE vs. goemetric mean diameter graph.

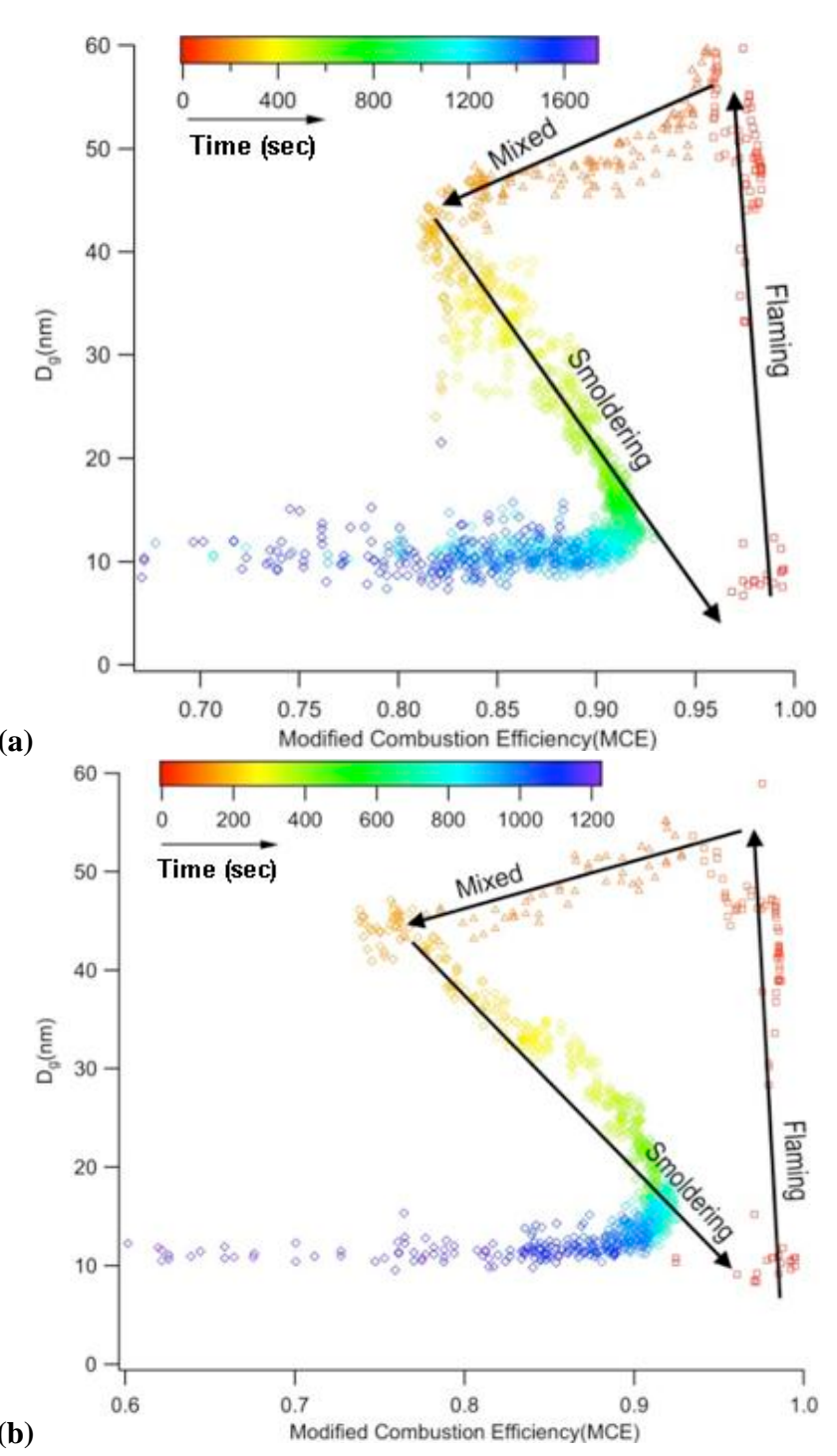

(b)

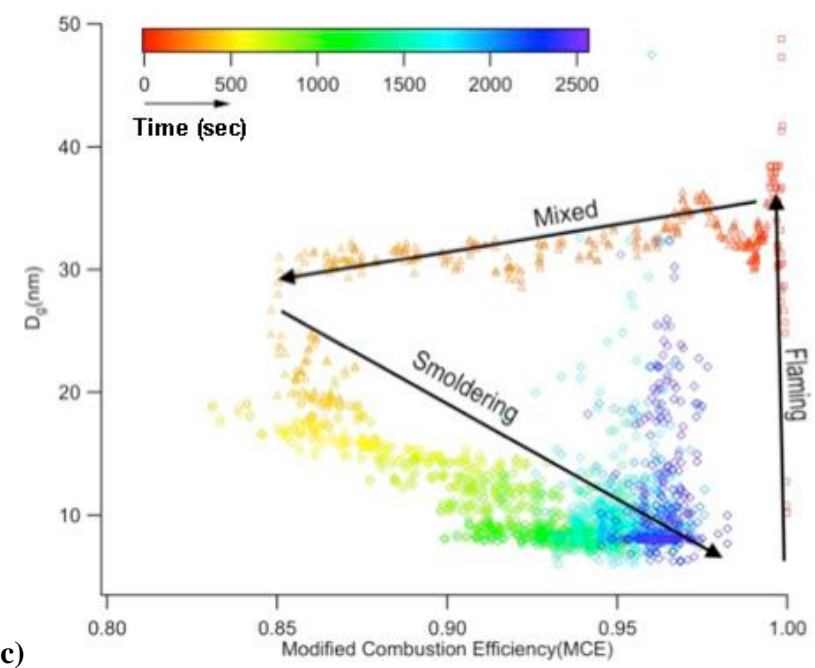

Fig. 9. MCE vs. Geometric Mean Diameter for three typical burns. 


\section{Conclusions}

This paper presented particle size distributions measured by a suite of fast-response online instruments for laboratoryscale biomass fires for a variety of southwestern US fuel types. The instruments measured evolution of particle size distribution from fire ignition to extinction to capture transient and integrated characteristics of the particle size distribution. Time-averaged particle size distributions were segregated into three combustion phases: flaming, mixed and smoldering. The major mode of particle size distribution was in the range of 29 to $52 \mathrm{~nm}$ for the cycle-averaged distributions. These are much smaller diameters compared to previous studies. The difference from previous studies was attributed to dilution of the fresh smoke in the current study. Time-averaged particle concentrations were highest during the flaming phase and gradually decreased during mixed and smoldering phases. Comparing mass size distribution from the FMPS and APS measurements, 51-68\% of particle mass was attributable to the particles ranging from 0.5 to $10 \mu \mathrm{m}$ for PM10. Geometric mean diameter rapidly increased during flaming combustion and gradually decreased during mixed and smoldering phase combustion. Particle size distribution was unimodal for most fuel types during the flaming phase and strongly biomodal during the smoldering phase. The slopes of the linear plots of MCE versus geometric mean diameter appear to better separate the combustion phases than simply using the value of MCE. Given the wide use of MCE alone to define combustion phases, additional measurement of particulate matter from biomass burning using fast response instruments is recommended.

\section{Supplementary material related to this article is available online at: http://www.atmos-chem-phys.net/10/8065/2010/ acp-10-8065-2010-supplement.pdf.}

Acknowledgements. Funding for this study was provided by the US Department of Defense Strategic Environmental Research and Development Program as projects SI-1647, SI-1648, and SI-1649. We appreciate the assistance of personnel at USMC Camp LeJuene, US Army Ft. Huachuca, Ft. Hunter-Liggett, Ft. Benning, and Vandenberg Air Force Base in selecting fuel types for study and fuel samples for burning. Authors are grateful to Robert Yokelson and Ian Burling for FTIR data and WeiMinHao and Shawn Urbanski; Cyle Wold, Joey Chong, Trevor Maynard and Emily Lincoln for their help.

Edited by: H. Moosmuller

\section{References}

Byun, D. W. and Schere, K. L.: Review of Governing equations, Computational Algorithms, and Other Components of the Models-3 Community Multi-scale Air Quality (CMAQ) Modeling Systems, Appl. Mech. Rev., 59, 51-77, 2006.

Capes, G., Johnson, B., McFiggans, G., Williams, P. I., Haywood, J., and Coe, H.: Aging of biomass burning aerosols over West Africa: Aircraft measurements of chemical composition, microphysical properties, and emission ratios, J. Geophys. Res.Atmos., 113, D00C15, doi:10.1029/2008JD009845, 2008.

Chakrabarty, R. K., Moosmuller, H., Garro, M. A., Arnott, W. P., Walker, J., Susott, R. A., Babbitt, R. E., Wold, C. E., Lincoln, E. N., and Hao, W. M.: Emissions from the laboratory combustion of wildland fuels: Particle morphology and size, J. Geophys. Res.-Atmos., 111, D07204, doi:10.1029/2005JD00665, 2006.

Chen, B. T., Cheng, Y. S., and Yeh, H. C.: Performance of a TSI Aerodynamic Particle Sizer, Aerosol Sci. Technol., 4, 89-97, 1985.

Chi, C. T., Horn, D. A., Reznik, R. B., Zanders, D. L., Opferkuch, R. E., Nyers, J. M., Pierovich, J. M., Lavdas, L. G., Mcmahon, C. K., Nelson, R. M., Johansen, R. W., and Ryan, P. W.: Source assessment: prescribed burning, state of the art, US Environmental Protection Agency, EPA (US) Report EPA-600/2-79-019h, November 1979.

Christensen, N. L.: Vegetation of the southeatern costal plain, in: North American Terrestial Vegetation, edited by: Barbour, M. G., W. D. B., Cambridge University Press, UK, 397-449, 1999.

Christian, T. J., Kleiss, B., Yokelson, R. J., Holzinger, R., Crutzen, P. J., Hao, W. M., Shirai, T., and Blake, D. R.: Comprehensive laboratory measurements of biomass-burning emissions: 2. First intercomparison of open-path FTIR, PTR-MS, and GC-MS/FID/ECD, J. Geophys. Res.-Atmos., 109, D02311, doi:10.1029/2003JD003874, 2004.

Countryman, C. M.: Physical characteristics of some northern California brush fuels, USDA Forest Serivce, Pacific Southwest Forest and Range Experiment Station, General Technical Report, 24, 1982.

Engling, G., Lee, J. J., Tsai, Y. W., Lung, S. C. C., Chou, C. C. K., and Chan, C. Y.: Size-Resolved Anhydrosugar Composition in Smoke Aerosol from Controlled Field Burning of Rice Straw, Aerosol Sci. Technol., 43, 662-672, 2009.

Goldammer, J. G., Statheropoulos, M., and Andreae, M. O., Goldammer, J. G., Statheropoulos, M., and Andreae, M. O.: Impacts of vegetation fire emissions on the environment, human health, and security: a global perspective, edited by: Bytnerowicz, A., Arbaugh, M., Riebau, A., and Andersen, C., Wildland Fires and Air Pollution, Elsevier, 8, 3-36, doi:10.1016/S14748177(08)00001-62009, 2008.

Goode, J. G., Yokelson, R. J., Susott, R. A., and Ward, D. E.: Tracegasmissions from laboratory biomass fires measured by Fourier transforminfrared spectroscopy: Fires in grass and surface fuels, J. Geophys. Res., 104, 21237-21245, 1999.

Hays, M. D., Geron, C. D., Linna, K. J., Smith, N. D., and Schauer, J. J.: Speciation of gas-phase and fine particle emissions from burning of foliar fuels, Environ. Sci. Technol., 36, 2281-2295, 2002.

Hays, M. D., Fine, P. M., Geron, C. D., Kleeman, M. J., and Gullett, B. K.: Open burning of agricultural biomass: Physical and chemical properties of particle-phase emissions, Atmos. Environ., 39, 
6747-6764, 2005.

Hedberg, E., Kristensson, A., Ohlsson, M., Johansson, C., Johansson, P. A., Swietlicki, E., Vesely, V., Wideqvist, U., and Westerholm, R.: Chemical and physical characterization of emissions from birch wood combustion in a wood stove, Atmos. Environ., 36, 4823-4837, 2002.

Hinds, W. C.: Aerosol Technology: Properties, Behaviour, and Measurement of Airborne Particles, Wiley Interscience, New York, USA, 316-349, 1982.

Keeley, J. E.: Chaparral, in: North American Terrestrial Vegetation, edited by: Barbour, M. G. and Billing, W. D., Cambridge University Press, NY, USA, 397-448, 1999.

Janhall, S., Andreae, M. O., and Pöschl, U.: Biomass burning aerosol emissions from vegetation fires: particle number and mass emission factors and size distributions, Atmos. Chem. Phys., 10, 1427-1439, doi:10.5194/acp-10-1427-2010, 2010.

Keshtkar, H. and Ashbaugh, L. L.: Size distribution of polycyclic aromatic hydrocarbon particulate emission factors from agricultural burning, Atmos. Environ., 41, 2729-2739, 2007.

Levine, J. S.: Biomass Burning and Global Change, MIT Press, 131-139, 1996.

Le Canut, P., Andreae, M. O., Harris, G. W., Wienhold, F. G., and Zenker, T.: Airborne studies of emissions from savanna fires in southern Africa, J. Geophys. Res.-Atmos., 8483, doi:10.1029/2002jd002291, 1996.

Pope, C. A. and Dockery, D. W.: Health effects of fine particulate air pollution: Lines that connect, J. Air Waste Manage., 56, 709742, 2006.

Pósfai, M., Simonics, R., Li, J., Hobbs, P. V., and Buseck, P. R.: Individual aerosol particles from biomass burning in southern Africa: 1. Compositions and size distributions of carbonaceous particles, J. Geophys. Res.-Atmos., 108(D13), 8483, doi:10.1029/2002JD002291, 2003.

Pósfai, M., Gelencser, A., Simonics, R., 5 Arato, K., Li, J., Hobbs, P. V., and Buseck, P. R.: Atmospheric tar balls: Particles from biomass and biofuel burning, J. Geophys. Res.-Atmos., 109, D22302, doi:10.1029/2008jd010216, 2004.

Rader, D. J. and McMurry, P. H.: Application of the Tandem Differential Mobility Analyzer to studies of droplet growth and evaporation, J. Aerosol Sci., 17, 771-788, 1986.
Reid, J. S., Koppmann, R., Eck, T. F., and Eleuterio, D. P.: A review of biomass burning emissions part II: intensive physical properties of biomass burning particles, Atmos. Chem. Phys., 5, 799825, doi:10.5194/acp-5-799-2005, 2005.

Stober, W. A.: A note on the aerodynamic diameter and the mobility of non-spherical aerosol particles, J. Aerosol Sci., 2, 453-456, 1971.

Sullivan, A. P., Holden, A. S., Patterson, L. A., McMeeking, G. R., Kreidenweis, S. M., Malm, W. C., Hao, W. M., Wold, C. E., and Collett, J. L.: A method for smoke marker measurements and its potential application for determining the contribution of biomass burning from wildfires and prescribed fires to ambient $\mathrm{PM}_{2.5}$ organic carbon, J. Geophys. Res.-Atmos., 113, D22302, doi:10.1029/2008JD010216, 2008.

Susott, R. A.: Characterization of the thermal properties of forest fuels by combustible gas analysis., Forest Sci., Society of American Foresters, 28, 404-420(17) 1982.

Wang, H. and John, W.: Particle Density Correction for the Aerodynamic Particle Sizer, Aerosol Sci. Technol., 6, 191-198, 1987.

Ward, D. E., Hao, W. M., Susott, R. A., Babbitt, R. E., Shea, R. W., Kauffman, J. B., and Justice, C. O.: Effect of fuel composition on combustion efficiency and emission factors for African savanna ecosystems, J. Geophys. Res.-Atmos., 101, 23569-23576, 1996.

Ward, D. E. and Radke, L. E.: Emission measurements from vegetation fires: a comparativeevaluation of methods and results, in: Fire in Environment. The Ecological, Atmospheric and Climatic Importance of Vegetation Fires, edited by: Crutzen, P. J. and Goldammer, J. G., John Wiley and Sons, New York, USA, 53-76, 1993.

Weise, D. R., Zhou, X. Y., Sun, L. L., and Mahalingam, S.: Fire spread in chaparral - 'go or no-go?', Int J. Wildland Fire, 14, 99-106, 2005.

Yokelson, R. J., Ward, D. E., Susott, R. A., Reardon, J., and Griffith, D. W. T.: Emissions from smoldering combustion of biomass measured byopen-path Fourier transform infrared spectroscopy, J. Geophys. Res., 102, 18865-18877, 1997. 